\title{
Inter-basin water transfer conflicts. The case of the Tagus-Segura Aqueduct (Spain)
}

\section{Alvaro-Francisco Morote*}

Department of Didactics of Experimental and Social Sciences,

Faculty of Teaching,

University of Valencia,

AvdaTarongers 4 46022, Apartado de Correos 22045 Valencia, Spain

Email: alvaro.morote@uv.es

*Corresponding author

\section{María Hernández and Antonio Manuel Rico}

Regional Geographic Analysis and Physical Geography Department, University of Alicante,

Carretera de San Vicente del Raspeig, s/n - (03080), Alicante, Spain

Email: maria.hernandez@ua.es

Email: am.rico@ua.es

\section{Saeid Eslamian}

Department of Water Engineering,

Isfahan University of Technology,

Isfahan, Iran

Email: prof.s.eslamian@gmail.com

\begin{abstract}
Since its inauguration in 1979, the Tagus-Segura Aqueduct has become one of the hydraulic infrastructures that have given rise to the highest number of inter-regional conflicts in Spain during recent decades. The aim of this paper is to analyse the political, social, environmental and economic conflicts presented in the donor (Tagus) and recipient (Segura) basins of this infrastructure. To this end, through the holding of interviews with the main stakeholders and an analysis of the regulations, an assessment has been made of the results (for and against) of those who defend maintaining this infrastructure, owing to its far-reaching social and economic impact, and those who advocate its immediate or progressive closure. In conclusion, the case analysed here has become one of the foremost inter-regional water conflicts in Spain which, currently, after the proposal and adoption of certain regulatory measures, continues to represent a conflict over water use that may be of interest and comparison in the international scope.
\end{abstract}

Keywords: transfers; conflicts; water; Tagus-Segura Aqueduct; Spain.

Reference to this paper should be made as follows: Morote, A-F., Hernández, M., Rico, A.M. and Eslamian, S. (2020) 'Inter-basin water transfer conflicts. The case of the Tagus-Segura Aqueduct (Spain)', Int. J. Hydrology Science and Technology, Vol. 10, No. 4, pp.364-391. 
Biographical notes: Alvaro-Francisco Morote is a Lecturer at the Department of Didactics of Experimental and Social Sciences at the University of Valencia (Spain). His research interests include studies about water consumption, the urbanisation process, and the study about the relation about new urban natures (gardens and pools) with water demand and natural hazards.

María Hernández is a Full Professor of Regional Geographic Analysis at the University of Alicante. Her research interests initiated in 1994 are focused on studies on analysis and evolution of rural and cultural landscapes, agriculture and rural development, tourism and local development, land management, demand and water uses, and natural hazards.

Antonio Manuel Rico is a Professor of Regional Geographic Analysis at the University of Alicante; he has focused his research in different geographical themes. He is the author or co-author of numerous publications (articles, book chapters and monographs). He has participated in several research projects on geographical, environmental and historical themes developed at the University of Alicante.

Saeid Eslamian is a Full Professor of Water System Engineering in the Department of Water Engineering at Isfahan University of Technology, Iran, where he was been since 1995. He research focuses mainly on water resources planning, management and sustainability, and statistical and environment hydrological in a changing climate.

\section{Introduction}

During the last century, the implementation of water transfers became one of the alternatives that generated the largest number of social and regional conflicts between donor and recipient basins (Del Moral and Silva Pérez, 2006; Gallego Bernad, 2013; Morote et al., 2017b; Thapa et al., 2018). The conflicts caused by transfers are directly related to a feeling of 'unfairness' in the decisions regarding the allocation of water resources and, increasingly, to the defence of the environmental and heritage values of the donor basins (Baeza, 2013; Ferreira, 2013; Lobanova et al., 2016; Kefayati et al., 2018; Li and Han, 2018; Venkatachalam and Balloni, 2018; Gómez, 2017; Gil et al., 2018). According to Zhuang (2016), the objective reality of uneven water resource distribution and imbalanced water demand of the human society makes water transfer inevitable. The adoption of the inter-basin water transfer (IBWT) has been an age-old method for alleviating and even resolving the urgent demand of water-deficient areas (Hernández Hernández et al., 2010; Gorostiza et al., 2017; Sánchez Pérez, 2018; López, 2018; Tan and Bi, 2018).

A number of countries have made attempts and have achieved enormous benefits with the adoption of the IBWT as the solution of water scarcity (Morote et al., 2017b; Tan and $\mathrm{Bi}, 2018$ ). However, IBWT inevitably involves the redistribution of water resources in relevant basins and may cause changes to the ecological environment and may also create water conflicts between the water source and recipient areas (Sun et al., 2017; La Roca and Martínez, 2018). Zhuang (2016) explains that such changes are two-sided: 
1 The positive impacts, including adding new basins for water-deficient areas, facilitating the water cycle, improving meteorological conditions in the recipient basins, mitigating ecological water shortage, repairing the damaged ecological system, and preserving endangered wildlife and flora.

2 Negative impacts, including salinisation and aridification of the donor basins; damage to the ecological environment of the donor basins and both sides of the conveying channel system; and increase of water consumption in the recipient basins and spread of diseases.

In the USA, for example, in the 1970s, the opposing sides proffered economic (high costs and funding difficulties), social (resistance by the local population to the construction of dams and water transfer) and environmental (impacts on ecosystems) reasons. During the following decades, the protests extended to developing countries, and today the fight against large dams and transfers constitutes one of the 'hot spots' of social-environmental conflict in Latin America, Asia and Africa (Mehta, 2011). There are many examples of interbasin transfers. Snaddon et al. (1999) identify more than one hundred big transfers in nearly 30 countries, the majority of which have been completed and commissioned. Ghassemi and White (2007) account for more than 50, including finished projects and proposals, in just five countries (the USA, Australia, Canada, China and India). Initiatives such as the Central Valley Project planned in 1933 in California (USA) to supply water for irrigation and supply in the Central Valley of California (Schwarz, 2015), the Snowy Mountains Scheme (Australia) (Poddar et al., 2014) and China's South-North Water Transfer Project (SNWT) (Sun et al., 2017), the world's largest transfer, are significant. In China, IBWT projects effectively overcome water shortages resulting from the uneven distribution of water resources and water demand (Tan and $\mathrm{Bi}, 2018$ ).

Rogers et al. (2016) show how the SNWT naturalises water scarcity, normalises the pre-eminence of North China, sustains engineering over regulatory solutions and reconfigures hydrosocial relations, while also outlining the limits to and endemic conflicts within this vast program of government. In South America, Hommes and Boelens (2017) analysed how urbanisation processes and associated irrigation-urban water transfers in the Lima region (Peru) created water control hierarchies that aligned the municipal drinking water company, hydropower plants, and rural communities in unequal postures. They also concluded that, more specifically, and beyond questions of outright water grabbing, perceived injustices involved the distribution of water-related benefits, loss of autonomy, and the socio-environmental impacts of territorial transformations. In Europe, the water framework directive (WFD 2000/60/EC) has led to the consideration of water-planning alternatives that place greater emphasis on the conservation of water masses, which has (according to some authors) turn led to a reconsideration of the subject of water transfers, owing to their considerable economic and environmental impact (Hernández-Mora, 2013; Morote et al., 2017a).

In Spain, although in the last 20 years they have been subjected to numerous criticisms as a result of a redirecting of objectives, methodologies, conceptual approximations and institutional changes (Saurí and Del Moral, 2001; La Roca and Martínez, 2018), more than 40 water transfers currently operate with a potential supply capacity of some $1,300 \mathrm{hm}^{3} /$ year, which represents less than $3 \%$ of the guaranteed resources calculated at $46,000 \mathrm{hm}^{3}$. The most notable transfers are those of the Tagus-Segura (650 $\left.\mathrm{hm}^{3}-1979\right)$, Ter-Llobregat $\left(229 \mathrm{hm}^{3} /\right.$ year - 1959), Ebro-Tarragona $\left(121.6 \mathrm{hm}^{3} /\right.$ year - 1989), Zadorra-Arratia $\left(150 \mathrm{hm}^{3} /\right.$ year - 1967), Guadiaro-Majaceite 


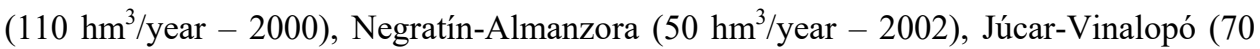
$\mathrm{hm}^{3} /$ year - 2011) and Ebro-Besaya $\left(26 \mathrm{hm}^{3} /\right.$ year - 1982).

According to Hernández-Mora et al. (2014), in Spain, semiarid and drought-prone areas have managed to meet ever-increasing water demands for more than 50 years through the construction of a publicly funded hydraulic infrastructure. IBWTs are the most expensive and complex supply-side tool used and they are also the most controversial, often associated with such unintended consequences as deteriorating freshwater ecosystems, disappearing recreational opportunities provided by aquatic ecosystems, and the loss of development opportunities for downstream communities. These authors explain that this situation has become increasingly unstable over the past decade due to the scarcity of new supply augmentation alternatives, political changes involving European Union environmental legislation, new political power in upstream regions, and the appearance of new stakeholders at the decision-making table. As a result, competing demands over available resources and interregional conflicts are delaying water planning management efforts, signalling the end of an era and demanding a shift from competitive use of water towards a shared water risk and trade-off governance approach.

In Spain, decision-making in water resource management is a perennial source of political debate (Del Moral et al., 2017; Molina and Melgarejo, 2016; Swyngedouw, 2015; Swyngedouw and Williams, 2016). When a basin suffers from a structural water shortage the possible solutions is either a transfer from another basin or the use of other unconventional resources such as those obtained through desalination or water reuse (Gil et al., 2017; Morote and Hernández, 2017; Morote et al., 2017b). However, according to López-Gunn et al. (2013), declaring a water crisis is a political move that backgrounds that scarcity is not the (only) issue in Spain. Politics and territorial interests have given rise to undesired fluctuations in water policy, in particular with regard to transferring water from one basin to another. The study of March et al. (2014) explores the new orientation taken by Spanish water policy since the beginning of the 21 st century and very specifically the shift towards desalination as an alternative to other water supply options such as river regulation or IBWTs. For solve these problems, Zhuang (2016) argues that there are some effective alternative measures for IBWTs, such as attaching importance to the water cycle, improving water use efficiency, developing seawater desalination and rainwater harvesting technology. Desalination also means a new and powerful element in water planning and management that could provide water for the continuous expansion of the urban and tourist growth machine in Mediterranean Spain and thus relax possible water constraints on this growth. However, by 2017 most new desalination plants along the Mediterranean coast remained almost idle even with the current drought (Morote et al., 2017a).

The Tagus-Segura Aqueduct (TSA), a water infrastructure that was in controversial since 1979 (year it went into operation), has been a topic analysed by the scientific literature (Gómez, 2017). The aim of this study is to analyse the postures for and against the TSA (Spain) synthesising background information, data and opinions in view of the political social, environmental and economic conflicts put forward by the donor (Castilla-La Mancha, Madrid and Extremadura) and recipient (Region of Murcia, the province of Alicante in the Valencian Community, and the province of Almeria in Andalusia) basins of this infrastructure. The hypothesis of this research is that the opposing postures around this water infrastructure have been accentuated over time. 
What this paper tries to add is to argue about the uncertainty about the TSA infrastructure and to analyse the reasons that have generated an accentuation of the debate of this infrastructure in the last years. These reasons are:

a Approval of new management rules more conservative and right for the donor basin (currently the limit for water transfer is set at $400 \mathrm{hm}^{3}$ in Entrepeñas and Buendía reservoirs (when before was $240 \mathrm{hm}^{3}$ in 2013).

b The implementation of new hydraulic policies associated with the construction of desalination plants for replacing water transfers in the recipient basin.

c Current drought (2015-2018) that has drastically reduced available water resources and has accentuated tensions over usage rights.

The study is structured as follows. After the introductory part which expresses the interest in the study of water transfer conflicts at an international level, the methodology are set out (Section 2), followed by a brief explanation of the functioning and characteristics of the case study of TSA (Section 3). The debate regarding the results for and against in the conflicts deriving from the TSA is then set out (Section 4) followed, finally, by the Discussions (Section 5) and Conclusions (Section 6).

\section{Methodology}

Methodologically, an analysis about how the normative framework regulates this transfer and the changes that have been introduced over time and how these are perceived by the different stakeholders of the donor and recipient basins had been made. In order to structure and organise the information obtained, a sheet was designed where it was differentiated:

a available resources and origin

b demands: present situation and medium and long-term trends

c actions oriented to satisfy the demands

d changes in regulatory frameworks and their impact on resources

e factors or future dynamics that may affect the supply or demand of resources.

To this end, regulations that bear a direct influence on the functioning of the TSA were analysed. Specifically:

a Water Framework Directive (Directive 2000/60/EC).

b Law 10/2001, of 5 July, on the Spanish National Hydrological Plan (PHN).

c Royal Decree-law 2/2004, of 18 June, which amends Law 10/2001, of 5 July, on the National Hydrological Plan.

d A.G.U.A. Programme (2004) (Actions for the Management and Use of Water, Royal Decree Law 2/2004).

e Law 21/2013 of 9 December, on Environmental Assessment.

f Royal Decree 773/2014, of 12 September (Memorandum). 
Law 21/2015, of 20 July, on Forestry.

h The Tagus Management Plan (Royal Decree 1/2016, of 8 January) and Segura Management Plan (Royal Decree 1/2016, of 8 January).

In second place, interviews have been held between 2016-2017 with different stakeholders of donors and recipient basins. The stakeholders interviewed and information compiled has been grouped into the following categories:

a Agricultural users: Central Board of Users of the Vinalopó-1'Alacantí (Junta Central de UsuariosdelVinalopó-l'Alacantí), Central Irrigators' Syndicate of the Tagus-Segura Aqueduct (Sindicato Central de Regantes del Acueducto Tajo-Segura - SCRATS), Association of Young Farmers (ASAJA) (Asociación Agraria de Jóvenes Agricultores).

b Urban and industrial users: Acuamed, Commonwealth of Canals of the Taibilla (Mancomunidad de los Canales delTaibilla-MCT).

c Political parties (PP, PSOE, IU and Podemos).

d Companies that supply water for urban uses: Hidraqua, Gestión Integral de Aguas de Levante, S.A., and Aguas Municipalizadas de Alicante, Empresa Mixta (AMAEM).

e Environmentalists' and citizens' associations: Environmentalist in Action, significant local platforms.

f Public organisations differentiating between those responsible for basin management: Segura Hydrographic Confederation and Tagus Hydrographic Confederation and political-administrative bodies (Department of the Environment, Department of Agriculture and Water of the donor regions and recipient basins, Public Water Body of the Region of Murcia, Water Agency of Castilla-La Mancha and Price Commission of the Valencian Government). In these categories are represented the stakeholders that affect this topic.

A structured interview was held, according to a common structure and script (Table 1) with the aim of collecting information regarding the postures for and against this water infrastructure according to political social, environmental and economic factors. Documentation analysing this transfer was also compiled, originating both from previous research works and from the organisations interviewed.

Qualitative information is collected given the method used (structured interview with open response). The results derived from the interviews with the different agents, together with the analysis of legal documents and other materials provided by the interviewees have been grouped into four types of conflicts (political, social, environmental and economic). These factors are not isolated elements, but they present interrelationships between them and even, sometimes, these interrelations accentuate the final result. But when structuring the paper and to keep the explanation simple, it is necessary to present them as different categories. The assignment to one or the other is determined by the origin of the factor and the main dynamic that generates it. The 'political conflicts' section includes the responses related to regulatory changes and how they affect its regulation. The 'social' section, issues related to the perception of this infrastructure. The 'economic', arguments concerning its impact on economic activities and in 'environmental', impacts on environmental drivers (water quality, quality of the ecosystems, etc.). 
Table 1 Interview questionary

1 Political factors:

1.1 Repeal of the National Hydrological Plan (2001) and approval of the A.G.U.A. Programme (2004). Point out the positive and negative repercussions that these normative changes have had for your basin.

1.2 What impact, according to you, has had the change in law that regulates transfer volumes in your basin? What repercussions do you think it may have in the future?

1.3 What role do you think the politicians have played in these changes?

1.4 Before a final closure of the TSA, what proposals do you think should be adopted?

2 Social factors:

2.1 The realisation of the transfer has guaranteed the supply for the different uses of your basin/area? If you have answered no, what are the causes that determine that this guarantee of supply does not occur?

2.2 Do you think that the policy of transfers in Spain has solved the problem of water scarcity?

2.3 Would you describe the transfer of resources as an appropriation? Why?

3 Environmental factors:

3.1 Do you think that the TSA has had positive environmental effects? Discuss the answer.

3.2 Point the main environmental effects associated with the TSA in relation to the following issues:

a State of the quality and quantity of water in Tagus River

b River Tagus landscape

c Status of the aquifers and overexploitation in the Segura basin

d Environmental flows for the Las Tablas de Daimiel National Park (donor basin).

4 Economic factors:

4.1 How would you rate the economic repercussions of the transfer to your territory, positive or negative? Point out the main reasons in which your answer is argued.

4.2 Indicate the main impacts derived from the TSA from the point of view of employment and development and consolidation of new economic activities.

4.3 Could you explain if the price of a $€ / \mathrm{m}^{3}$ of water from the transfer is adequate? Why?

4.4 Financial compensation of the transfers. Do you know what they are? If the answer is positive, could you explain what its purpose is? Do you think it is an adequate tool?

Discuss the answer.

Source: Own elaboration

\section{The case study of the TSA. Characteristics, functioning and recent amendment of its management rules}

In Spain, to summarise briefly, the recent history of water management since the beginning of the 20th century was marked by: There generation is approaches of the General Plan for Irrigation Channels and Aqueducts of 1902 (backed by the minister Gasset); the creation of the Hydrographic Confederations (during the Primo de Rivera Dictatorship, 1923-1930); and the preparation of the First National Plan of Hydraulic 
Works (1933) of Manuel Lorenzo Pardo (during the Second Republic, 1931-1936) the basic lines of which were included in the General Plan of Public Works of 1940. Although there are many nuances, the general approach of these national hydraulic plans was to promote the economic and social transformation of Spain and, in the specific case of the First National Plan of Hydraulic Works (1933), its essential guiding principle was the correction of the hydrographic imbalances between the Atlantic and Mediterranean coasts (Gil and Morales, 1995).

These state plans promoted the transformation of dry lands to irrigated lands, as a developmental alternative backed by institutions with enough power to put them into practice, although with an uneven and fragmented trajectory over the course of the 20th century: Monarchy (Kingdom of Alfonso XIII, until 1931), Second Spanish Republic (1931-1936), Civil War (1936-1939) and Dictatorship of Francisco Franco (1939-1975). Subsequently, with the establishment of democracy in 1978 and a new constitutional setting, Spain was divided into 17 autonomous communities that assumed a wide range of competences (health, education and social policy, management of natural resources, environmental policy and land use management). In the last one hundred years, investment in hydraulic infrastructure (public and private) has resulted in the construction of over 1,200 large reservoirs, more than 20 major desalination plants and various transfers of different capacities and regional importance (Hernández-Mora et al., 2014; Morote et al., 2017a).

In order to guarantee water demands in the south-east of Spain (Region of Murcia, Alicante in the south of the Valencian Community and Almeria in Andalusia), which is the area that benefits from the TSA (Segura basin), use has been made of traditional hydraulic solutions (such as transfers and exploitation of aquifers) together with growing use of non-conventional sources (desalination and treated water) and the increased efficiency in the use of water for irrigation and supply (Rico et al., 2016). In the Segura basin, the imbalance between the supply $\left(1,636 \mathrm{hm}^{3} /\right.$ year $)$ and the demand $(1,726$ $\mathrm{hm}^{3} /$ year) for water responds, above all, to the natural scarcity of water resources, increased consumption and the qualitative mutations that have affected the majority of uses since the second half of the 20th century (Hernández and Morales, 2009; Vera et al., 2009; Morote et al., 2016).

The TSA (maximum annual transfer capacity of $650 \mathrm{hm}^{3} /$ year (50 for the Guadiana basin and 600 for the Segura Basin) and a mean transfer between 1979-2017 of 330 $\mathrm{hm}^{3} /$ year) (Figure 1) consists of a canal of 286 kilometres in length that begins in the Bolarque reservoir $\left(35 \mathrm{hm}^{3}\right)$ on the river Tagus, downstream from the headwater reservoirs (Entrepeñas, $804 \mathrm{hm}^{3}$ and Buendía, 1,638 $\mathrm{hm}^{3}$ ) (Figure 2). From Bolarque, after pumping in Altomira, the water is situated in the La Bujeda reservoir ( $884 \mathrm{~m}$ above sea level), the starting point for the transfer canal (with a capacity of $33 \mathrm{~m}^{3} / \mathrm{s}$ ) towards the hyper-reservoir of Alarcón $\left(1,112 \mathrm{hm}^{3}\right)$, on the river Júcar, and from there to the Talave reservoir $\left(39.11 \mathrm{hm}^{3}\right)$ on the river Mundo, principal tributary of the Segura. This latter reservoir marks the starting point for the 'Post-transfer' complex, which constitutes the set of structures built for the transport, regulation and distribution in the Segura basin of the water from the TSA.

The volumes of water that can be transferred from the Upper Tagus to the Segura Basin depend on the water resources accumulated in the headwaters (dams of Entrepeñas and Buendía). Pursuant to that set forth in Article 23 of the Tagus Basin Management Plan approved in 1998 surplus water is deemed to be any water held in the Entrepeñas 
and Buendía reservoirs exceeding $240 \mathrm{hm}^{3}$. Below this figure, no transfers may be made. To determine surplus volumes, according to the regulations of Additional Provision 9.2 of the Law 53/1980, the following shall be taken into account:

a the potential uses referred to by the Law 21/1971 on the use of the Tagus-Segura complex

b the uses as a consequence of the natural development of the provinces of the Tagus basin.

The draft proposal for the basin management plan of the Spanish Part of the Tagus River Basin District (2013) included in its technical documentation (Report and Ancillary Document of Report 4) and in the draft Regulations (Article 26 and sole Transitory Provision) a series of determinations that would significantly affect the way the TSA had functioned until then. Article 26 established that 'no transfers may be made, in any case, when the levels in Entrepeñas and Buendía do not exceed $400 \mathrm{hm}^{3}$. This determination meant that the minimum 'no transfer' threshold was raised from 240 to $400 \mathrm{hm}^{3}$, with a maximum annual total $600 \mathrm{hm}^{3} /$ year (in origin) and $540 \mathrm{hm}^{3} /$ year (in destination due to losses and evaporation).

Figure 1 Water transferred by the TSA (1979-2017) (see online version for colours)

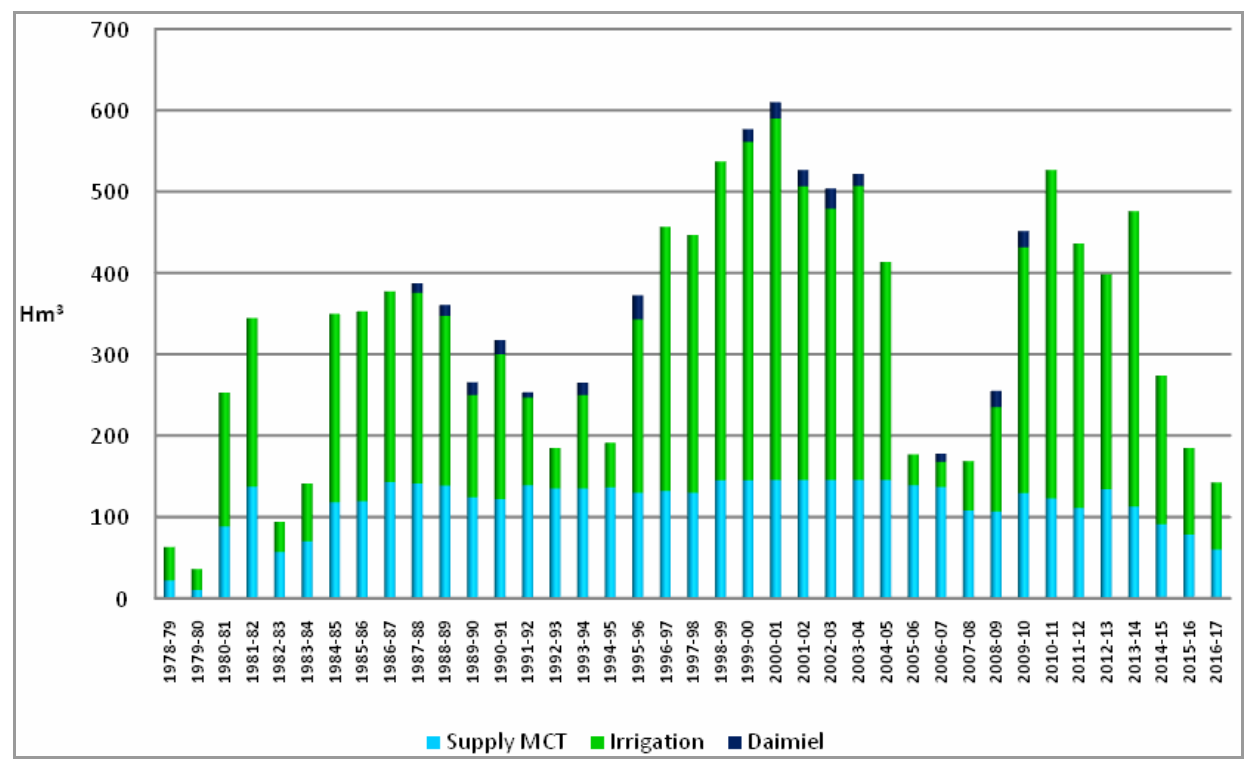

Source: SCRATS (2017), Own elaboration

In the light of the legal and technical insecurity that beset the TSA, the Government of Spain introduced, via the Environmental Assessment Law (Law 21/2013), a series of amendments in the water legislation with the aim of establishing a system of guarantees of the future functioning of this infrastructure which has substantially modified the TSA functions. Always maintaining the preference of the source basin and respecting the determinations of its hydrological management, this regulation established some technical rules that eliminated the previous insecurity and precariousness (the transfer was only closed when the headwater reserves were below $240 \mathrm{hm}^{3}$ ) and provided 
objective and transparent criteria regarding the manner of operation of such transfer (Melgarejo et al., 2014; Morote et al., 2017b). These new management rules were established by the 15th additional provision of the Law 21/2015, Forestry and by Royal Decree 773/2014, which approved various regulatory rules of the TSA. Moreover, they have been included in a 'memorandum' between the Spanish Government and the Autonomous Communities of Murcia and Valencia (recipient basin), and were subsequently joined by the Communities of Castilla-La Mancha, Madrid, and Extremadura (donor basin) (Melgarejo et al., 2014).

Figure 2 Tagus and Segura basins and the TSA

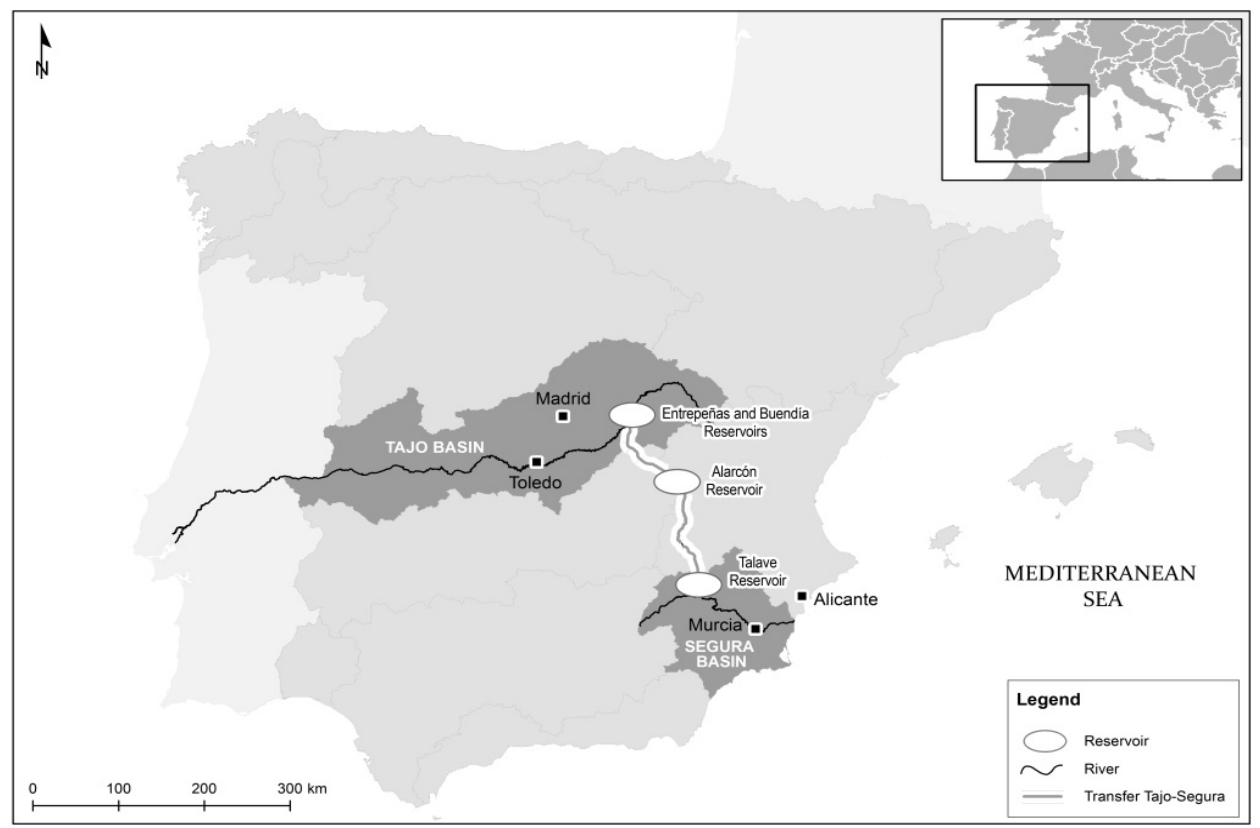

Source: Own elaboration

\section{Results. The TSA: an example of a national water conflict}

\subsection{Political conflicts}

In Spain, the autonomous communities affected by possible transfers, whether as donors or recipients of water, try to prevent or guarantee them via the reform of their respective statutes of autonomy (Mellado, 2010). This process demonstrates not only the difficulty faced by the Autonomous Community Government to reach agreements of consensus between the different regions, but also the facility with which the 'water nationalism' discourse is replicated and is susceptible to be used by all the autonomous community governments such as, for example, between Castilla-La Mancha, Madrid and Extremadura (Tagus basin) on the one hand, and Murcia, Andalusia and the Valencian Community (Segura basin), on the other. 
The Ministry of Environment has been in charge of water policy since before 2001 . Furthermore, it has increased the risk of confrontation between regions, instead of supporting formulas for solidarity, participation and cooperation between regions to share solutions and problems regarding water management and quality.

There is also a wide spread idea that transfers only generate prejudice, with the argument that there is not enough water in the headwaters of the Tagus, which has become one of the arguments used by the politicians of Castilla-La Mancha (PSOE) in their speeches. In the recipient basin, on the other hand, the TSA was defended as an infrastructure of vital importance for socio-economic development by the conservative governments that governed in the Valencian Community and the Region of Murcia (PP) until the elections of May 2015, and even by the current left wing the regional government (PSOE-Podemos) which is in turn the same colour politically as the autonomous government of the source basin.

The complaints of the 'anti-transfer' groups were presented in 2016 to the European Parliament, including the appeals presented against the so-called Tagus-Segura Transfer Memorandum (2013). This led to the visits to the Spanish basins of the MEPs of the European Parliament (February 2016) for the purpose of inspecting the terrain and opening a dialogue with the national authorities regarding the TSA and the alleged breach of the WFD. Some of the recommendations made after these visits were that the management model for water resources in Spain should be changed completely. Conditioning the possible distribution of use to compliance with the environmental requirements of the WFD and the management plans of the basin and giving priority to environmental over socio-economic requirements. Even so, the MEPs, in their report, do not refer directly to the continuity of the TSA, although they mention the scarcity of water in the eastern area of Spain owing to climate change, uses related with urban pressure and intensive irrigation, as well as tourism activities. And, moreover, they explain that the solutions lie in transfer and desalination, the latter technology being subsidised by funds from the European Union (European Parliament, 2016).

In the south-east of Spain, the use of desalination (National Hydrological Plan, 2001 and the A.G.U.A. Programme, 2004) has become one solution for increasing the supply of water resources in the area, although it is not clear that this is the solution to the lengthy controversy around the TSA. In the recipient basin, taking in to account the total capacity of desalination production in the main seven plants $\left(350 \mathrm{hm}^{3} /\right.$ year $)$, has never reached this volume due to the high price of water, the high cost of energy, and because the irrigators cannot pay for it (Morote et al., 2017a). According to Swyngedouw and Williams (2016), desalination looks set to become the great solution, although at the moment it is economically more expensive and unfeasible for agricultural use unless a political price is applied. In this respect, the province of Alicante (recipient basin) is home to the desalination plant of Torrevieja (completed in 2010), which is the largest in Europe with a production capacity of $80 \mathrm{hm}^{3} /$ year and which began to produce water in 2015 with a capacity of $30 \%$ (in 2017 with a capacity of $50 \%$ ), but with subsidised water until 2018 under the auspices of the Drought Decree for agricultural use with a price of $0.30 € / \mathrm{m}^{3}$. Furthermore, according to the detractors of the TSA in the donor basin, the desalination plants built on the Mediterranean coast should produce subsidised water (at a price equal to that of the TSA, at $0.09 € / \mathrm{m}^{3}$ ). At present this is an unfeasible solution, even though desalination is a strategic resource for circumstantial alleviation of the decrease of other resources (as has occurred with the river Taibilla,a tributary of the Segura) or with the TSA. It cannot be considered as a substitute resource in the 
long-term, owing to the price $\left(0.09 € / \mathrm{m}^{3}\right.$ compared to $0.60 € / \mathrm{m}^{3}$, of the desalination) and to energy consumption $\left(1.11 \mathrm{kWh} / \mathrm{m}^{3}\right.$ compared to $4.50 \mathrm{kWh} / \mathrm{m}^{3}$ ) (Morote et al., $2017 \mathrm{~b}$ ). Moreover, it is important to note that transferring water from the coast inland $(100 \mathrm{~km}$ from the coast, and $500 \mathrm{~m}$ above sea level) will increase energy costs and, therefore, the cost of water.

\subsection{Social conflicts}

The social tensions surrounding the TSA have led to the establishment of numerous organisations and platforms, both for and against, ever since the transfer commenced. As long ago as the 1970s, with the aim of defending the water interests of the river Tagus, the 'Tagus Defence Team' (Plataforma en Defensa del Tajo) was formed as the first organisation to safeguard the values of this river where it passes through Toledo (Capital of Castilla-La Mancha). The visibility of these platforms and their capacity to bring together groups and the general population increases during episodes of drought. Such episodes lead to a reduction in the flow of the Tagus, which has even been known to dry up, as occurred in the summer of 1995 in Toledo and in 2006 in the city of Talavera de la Reina. The intensity of these processes determined, for example, the founding of the 'Platform in Defence of the Alberche and Tagus Rivers' (2006) and the holding of numerous demonstrations to vindicate their postures against the TSA. Owing to its significance in the area of Castilla-La Mancha and thanks to the mobilisation of the inhabitants of the region and the dissemination in the media, it is appropriate to mention different demonstrations against to the TSA. For example, the demonstration of 20 June 2009 held in Talavera de la Reina which brought together, according to estimates, more than 40,000 people of different social and cultural groups, environmentalists and people linked to environmental law, who shared and demonstrated over the 'bleeding' of the Tagus in favour of transfers to the south-east of Spain (Plataforma de Toledo en Defensa del Tajo, 2016).

The arguments against the TSA put forward by the Toledo Platform in Defence of the Tagus are:

a The establishment of real daily, weekly and monthly ecological flows, reflected in the Tagus Basin Management Plan, in the cities of Aranjuez, Toledo, Talavera de la Reina and Puente del Arzobispo.

b The start-up of the desalination plants on the Mediterranean coast for the purpose of replacing the contributions of the TSA and, while such substitution is being carried out, the water transferred may not be allocated to irrigation.

c Absolute prohibition of the sale, by the irrigators of the Tagus, of their allocations for irrigation to other water basins.

d Tertiary treatment of the waters of the Jaramaand the Guadarrama.

e Guarantee of the minimum ecological flow in the river Alberche, apart from the allocations of irrigation water for the Lower Canal of the Alberche.

f The absolute refusal to transfer flows from the middle Tagus, either via new channels or via the sale of water to other basins. 
g The performance of actions to help recover the natural regime of the river and its environment.

Moreover, it is important to mention that Portuguese NGOs are part of the network of civil society defending Tagus. In this respect, the Albufeira Convention (1998) establishes a minimum of $2,700 \mathrm{hm}^{3}$ delivered for the Tagus from Spain every year.

Also prominent in the scope of the defence of the river Tagus, as with other rivers affected by transfers, is the New Water Culture Foundation (Fundación Nueva Cultura del Agua, FNCA, 2016), which defends the recovery of the heritage, cultural, emotional, aesthetic and leisure values of Spanish rivers and water landscapes (La Roca and Martínez, 2018). The FNCA affirms that the conflicts surrounding the TSA since its origin are twofold. On the one hand, the insistence on solving problems of supply-demand imbalance by means of the supply of water at low cost. On the other hand, the design errors that led to a project for transfer from the headwaters of a basin while underestimating its available resources. The result has been, according to its arguments, an infrastructure that has only served to share scarcity, generate political and social tensions and convert the river Tagus into one of the Spanish rivers with the worst ecological condition.

In the recipient basin, on the other hand, numerous demonstrations have also been held in favour of the TSA such as those of 18 March 2009 in Murcia in which more than 400,000 people assembled (according to estimates by the Local Police) under the slogan 'In defence of the Tagus-Segura Transfer. No to the Statute of Autonomy of Castilla-La Mancha'. These demonstrations are connected to those held under the slogan of 'Water for all', where various groups (the majority headed by political groups, farmers, etc.), argued the need for water in the scope of insufficient water resources. Images of thirsty fields were compared with rivers flowing out into the sea. The last demonstration in favour of the TSA was held in Madrid (50,000 people) in March, 7th 2018 to request the government to adopt measures to cope the currently drought and the TSA maintenance. Some of the slogans were 'If we are a country, why divide it?' or 'desert and unemployment' (CMM, 2018).

With regard to public opinion, according to the Department of Public Administrations of Castilla-La Mancha, $65 \%$ of residents of this region are against the TSA and $72.6 \%$ consider it is important for Castilla-La Mancha to have exclusive competence in the decisions and actions performed in the management of the rivers of that autonomous community. On the other hand, in the study by March et al. (2015), a consultation was carried out of the population of the recipient basin regarding the perception of the population, assessing the effectiveness of the environmental awareness campaigns during periods of drought in the event that it should prove necessary to increase water resources. The most highly-valued options were, in order of preference:

1 the use of rain water

2 increase of TSA transfers

3 the performance of the cancelled Ebro transfer

4 the utilisation of treated reused water

5 the use of desalinated water. 
Against these theses, one of the arguments put forward by the defenders of the TSA is the social benefits deriving from the functioning of this infrastructure as it passes through land in Castilla-La Mancha (donor basin). In this respect, it should be indicated that in January 2000 a Collaboration Protocol was signed between the Ministry of the Environment, the Regional Government of Castilla-La Mancha and the Hydrographic Confederation of the Guadiana, for the connection for the supply of drinking water to 33 population nuclei in the donor basin (provinces of Cuenca, Albacete and Ciudad Real) thanks to the TSA infrastructure and also, nowadays, thanks to TSA, in 59 villages of the donor basin, water supply is guaranteed.

\subsection{Environmental conflicts}

The postures against the TSA from the environmental point of view can be summarised in the endeavour to adopt more sustainable regional models and the criticism of environmental impacts. Groups of environmentalists, in both donor and recipient basins, reject water transfers and advocate sustainable agriculture. They also criticise the 'double standards' of the Government of Castilla-La Mancha since it contemplates in its Statute the repeal of the TSA but, however, the maintenance of the Tagus-Guadiana Transfer (also an interbasintransfer, although within the same region). Likewise, left-green political groups (of both the donor and recipient basins) point to the wish to close the TSA for south-east Spain but, on the other hand, the acceptance that the water of the river Tagus may be allocated to the large urban developments contemplated in Castilla-La Mancha: Ciudad Real, Seseña (Toledo) or the proliferation of urban developments such as 'La Losilla' (Chinchilla, Albacete) with 1,800 houses and a golf course (Sala, 2009). In this respect, the new Tagus Management Plan (2015-2021) argues that the strong demographic growth of the Community of Madrid and Castilla-La Mancha must be supplied from resources regulated at the headwaters (Entrepeñas and Buendía reservoirs) since they lack other possibilities. Thus the increase of the non-transferable reserve in the headwaters (from 240 to $400 \mathrm{hm}^{3}$ ) is related to the increase in urban demand expected in the southern belt of Madrid with paradigmatic examples such as Seseña (province of Toledo). This plan envisages that water demand in the headwaters of the river Tagus will increase between 2015 and 2033 by almost $184 \mathrm{hm}^{3}$, especially urban demands which will increase from 741 to $931 \mathrm{hm}^{3}$ and industrial demands from 42 to $61 \mathrm{hm}^{3}$. With regard to irrigation, it should be indicated that the number of hectares irrigated (except in the Community of Madrid), has risen in the last decade from 447,333 ha in 2002 to 512,223 ha in 2014 in Castilla-La Mancha (Table 2).

Table 2 Main uses and demands of water (urban, irrigation and industrial) of the Tagus and Segura basins (2015-2021)

\begin{tabular}{lccccc}
\hline & \multicolumn{2}{c}{ Tagus } & & \multicolumn{2}{c}{ Segura } \\
\cline { 2 - 3 } \cline { 5 - 6 } \cline { 5 - 6 } & $\mathrm{Hm}^{3}$ & $\%$ & & $\mathrm{Hm}^{3}$ & $\%$ \\
\hline Urban & 741.32 & 27.32 & & 189.1 & 11.22 \\
Irrigation & $1,929.37$ & 71.10 & & $1,487.1$ & 88.23 \\
Industrial & 42.54 & 1.56 & & 9.1 & 0.53 \\
Total & $2,713.23$ & 100 & & $1,685.3$ & 100 \\
\hline
\end{tabular}

Source: Plans for Hydrographic Demarcation (2015-2021), Tagus and Segura 
The defenders of the TSA also state that this infrastructure has seen an increase in its area of influence with the so-called environmental demands. This has been reflected thanks to the allocations contemplated in the Law 13/87, for the diversion of volumes of water from the upper basin of the Tagus via the TSA destined for the National Park of the Tablas de Daimiel (Castilla La-Mancha), owing to the descent of the water table as a result of the overexploitation of the aquifers that feed them due to the opening of wells for irrigation, which allowed the transfer to this wetland of up to $60 \mathrm{hm}^{3}$ every three years, while not exceeding $30 \mathrm{hm}^{3} /$ year. Since 1987, a total of $256 \mathrm{hm}^{3}$ has been diverted for environmental use in aid of this National Park. Furthermore, the irrigators of the south-east of Spain argue that the water transferred is only the surplus in the Tagus basin, that is, the water that is left over after attending to all the priority demand, including environmental, in the donor basin.

The environmentalists groups and the main users of the TSA in the recipient basin (SCRATS for irrigation and MCT for urban uses) affirm, likewise, that the cancellation of this infrastructure would imply a breach of the regulations of the WFD, both owing to the deterioration of the water bodies as its volume and quality are reduced, and since it would affect the ecosystems that depend on them in the recipient basin. The reduction in the flow of water in the rivers would be caused by the loss of external contributions in the flow circulating in stretches of rivers with transfer water. And, to a lesser extent, by the loss of irrigation run-off from the areas irrigated with water from the Tagus that surround the watercourses (Vicente and Richard, 2009).

Furthermore, the closure of the TSA would imply a greater over exploitation of the groundwater in the south-east of Spain, causing an impoverishment of the ecosystems as their biodiversity is reduced and they lose their capacity for regeneration. Moreover, this intensive exploitation of the aquifers has led in many cases to the salinisation of the groundwater owing to the recirculation of irrigation waters or the intrusion of seawater. This is the case, for example, of the aquifers of Campo de Cartagena (Murcia), which in the 1970 s pumped up to $120 \mathrm{hm}^{3} /$ year, whilst, thanks to the TSA, the extractions have been reduced by up to 50\% (Martínez and Senent, 2007). They likewise affirm that the water from the river Tagus has an indirect impact on the management of salts in the ground, since the salinity of this water is lower than the levels in the water applied to the fields originating in the aquifers and river, which enables a mitigation of the salinisation process in the ground of these lands (Vicente and Richard, 2009). Besides, if the TSA will replace by desalination, $\mathrm{CO}_{2}$ emissions will increase in the recipient basin due to an increase in the production capacity of this non-conventional resource $\left(4.50 \mathrm{kWh} / \mathrm{m}^{3}\right.$ in comparison with $1.11 \mathrm{kWh} / \mathrm{m}^{3}$ of the TSA) (Morote et al., 2017b).

\subsection{Economical conflicts}

The TSA has had considerable economic consequences in the donor basin of the Tagus. Initially, the villages around the Entrepeñas and Buendía reservoirs were the first to suffer the impacts of the loss of their fertile fields as a consequence of the construction of these reservoirs in the middle of the last century, at a time when agriculture was the principal means of making a living. Subsequently, these villages developed an economy based on tourism and the leisure use of the reservoirs, around what was known at the time as the 'Sea of Castilla', but these new resources have been affected by the fluctuation of the flows, linked to droughts and the transfer of volumes to the south-east of Spain 
(Hernández-Mora, 2013). In this respect, in 1980, the resources available in the headwaters had decreased by approximately 47.5\% (Estevan et al., 2007).

Another of the arguments against the TSA is that the water transfers should be replaced in favour of the commissioning of the desalination plants built on the south-east coast of Spain (an installed capacity of $350 \mathrm{hm}^{3} /$ year in the Segura basin) during the last decade, which are practically unused (Swyngedouw and Williams, 2016), and that the production of water should be subsidised at a cost equal to the water of the TSA $(0.09$ $\left.€ / \mathrm{m}^{3}\right)$. However, it should be borne in mind that these affirmations do not take into account the sharp increase in energy costs involved in pumping the water inland from the coast, as well as the increase in $\mathrm{CO}_{2}$ pollution since the production of desalinated water multiplies by four the energy consumption of the TSA $\left(4.50 \mathrm{kWh} / \mathrm{m}^{3} \mathrm{vs} .1 .11 \mathrm{kWh} / \mathrm{m}^{3}\right)$. In relationship with the use of desalinated water, the defenders of the TSA argue that this does not constitute an alternative to the TSA (maximum of $600 \mathrm{hm}^{3}$ annual transfer) at least for irrigation, and that it should be considered a complementary resource, but never an ordinary source, owing to problems of water volume and, especially, the price that may oscillate between $0.60-1 € / \mathrm{m}^{3}$ depending on the plant and production).

The defenders of the TSA affirm, however, that this infrastructure has enabled the socio-economic development of the south-east of Spain (agricultural activity and supply for urban and tourism uses). In the recipient basin, the TSA, in years of normal rainfall, not only supplies approximately a third of the total resources of the Segura basin, but also currently benefits 147,276 ha of horticulture and fruit for export comprising 54,121 ha of vegetables, 61,316 ha of citrus fruits and, 1,603 ha of cultivation under plastic, owing to its higher output and economic and social impact. By regions, Murcia irrigates 85,397 ha with water from the Tagus, Alicante 58,878 ha and Almeria 3,000 ha. All of this has an annual repercussion on national gross domestic product (GDP) of about 2.364 billion euros, and supplies water to 80,000 irrigators, enabling 104,000 direct jobs (SCRATS, 2016). In this respect, of the 11.903 billion euros marketed in vegetable and fruit exports in Spain in 2015, 42\% was marketed in the area benefiting from the TSA (4,999 billion euros). Especially significant is the case of the vegetables of this region, which represent $68 \%$ (3.286 billion euros) of the vegetables marketed in Spain (FEPEX, 2016). And furthermore, these water transfers guarantee supply to more than 2.5 million inhabitants in the recipient basin (provinces of Almeria, Alicante and Murcia), with a nearby area of influence of $20,000 \mathrm{~km}^{2}$ that could increase in 1 million more due to the touristic uses in summer (San Martin, 2011).

Together with the arguments that the assignment of these resources would mortgage the future economic and social development of the donor region (Morales et al., 2005), one of the most controversial matters is the price of the water. This would be determined in Article 7 of the Law of 1971 (authorisation of water transfers from the headwaters of the Tagus to the Segura basin) which stated that 'the fee will include the amounts corresponding to the following concepts:

a the costs of the building work

b the fixed maintenance expenses

c the variable working expenses.

The amounts collected for the concept of the cost of the building work (result of dividing the total cost of the work performed by the annual amount of water transferred) would be 
allocated preferentially to the performance of hydraulic works in the Tagus basin, regardless of the amounts allocated in the General State Budgets for investments in the region' [Melgarejo, (2000), p.76].

Annuities paid by users of the TSA in the period 1979-2005 amounted to 1,059.4 million euros, distributing 313.6 million for amortisation of hydraulic work, 154 for the impact of fixed costs and 591.8 for variable costs. All this, makes an average of about 41 million euros per year (1979-2017). However, if episodes of drought had not been taken into account, it would have amounted to 55 million euros (González-Escolano, 2009). The transfers, in current value, made to the donor autonomous communities amount to 412,558 million euros, 183,36 million euros being distributed to Castilla-La Mancha (44\%), 137,52 to the Community of Madrid (33\%) and 91.68 for Extremadura (22\%) (SCRATS, 2016).

However, the defenders of the TSA affirm that the users of the transfer pay $100 \%$ of the costs of the water they receive according to the cost recovery principle and to date they have compensated the autonomous communities of the Tagus Basin. Furthermore, they argue that in the donor basin these economic resources should have been used as a priority to attend to the water infrastructure needs in the riparian villages of the Entrepeñas and Buendía reservoirs (Melgarejo and Martínez, 2009). In this respect, they have warned on several occasions that the existence of this regional compensation should be explained more appropriately in the budgets and investments made in the beneficiary autonomous communities, to ensure that the inhabitants of the donor basin are aware of it.

In relationship with the price of the water, one of the recommendations proposed by the detractors of the TSA in the complaints to the European Parliament (February 2016) is that the users of the TSA did not pay the full price of the water and that this should be charged at its full cost and not at the current fees since, according to them, the fees are heavily subsidised. Currently, the cost of the transferred water is $0.09 € / \mathrm{m}^{3}, 40 \%$ less in real costs than when the transfer began $\left(0.15 € / \mathrm{m}^{3}\right)$ and $50 \%$ less than the price paid for that water on the so-called 'water market' between the basins during the drought of $2005-2008\left(0.18 € / \mathrm{m}^{3}\right)$.

\section{Discussion}

One of the main problems of the water management in Spain is that the autonomous communities have taken a leading role, frequently forgetting that the legal basis for the transfers lies in the state ownership of the public hydraulic domain. This is due, partly, to the lack of decisiveness of the Spanish State when promoting decisions regarding the use and destination of water in Spain (an asset of public interest) and to solve the problems generated by its scarcity (Morote et al., 2017b). In this respect, an essential feature in the development of Spanish water policy during the second half of the 20th century has been the rapid commitment to a supply policy (irrigators, suppliers, hydroelectric power stations and construction companies). These parties have different interests that condition the adaptation of a water policy in line with the new social demands and the requirements of the WFD. For this purpose, it is necessary to design institutional mechanisms that can be combined in the long and short term without compromising the adaptation to the new realities and changes of decision. Therefore, as stated by Hernández-Mora et al. (2014), participation should be a key element in decision-making, yet it has little effect because 
people do not understand each other, where changes are necessary in mindsets and power structures and there is a need for national interests to converge with management perspectives that defend regional interests. In this line, Morales et al. (2005) affirm that the maintenance of these infrastructures will depend on their acceptance by Spanish society provided that this redounds to a benefit for all the autonomous communities, over and above the local interests of the different areas.

The realisation of transfers of the TSA has generated diverse and continuous controversies between the donor and recipient basins (Table 3). These postures in favour and against were aggravated by the fact of the success of the different factors

1 Approval of new management rules (currently the limit for water transfer is set at $400 \mathrm{hm}^{3}$ in Entrepeñas and Buendia reservoirs, when before was $240 \mathrm{hm}^{3}$.

2 The effects of climate change (reduction in the water quantities by 7\%) (Tagus Hidrological Plan, 2015-2021) and a greater recurrence and intensity of drought episodes as the currently episode 2015-2018 that has drastically reduced available water resources and has accentuated tensions over usage rights.

3 The implementation of new hydraulic policies associated with the construction of desalination plants in the recipient basin that increases the available water resources and allow to replace water transfers.

4 Increase of the water demand in the donor basin (2015-2033) according to the Tagus Hydrological Plan $\left(184 \mathrm{hm}^{3}\right)$.

The amendment of the management rules of the TSA is more conservative, just and adapted to the new needs and realities of the donor basin than the previous ones. It has determined a considerable increase in the no-transfer threshold in the headwater of the river Tagus (Entrepeñas and Buendía reservoirs) that also affects rules that determine the emergency and alert levels. Thus, its functioning capacity has been limited in comparison with previous requirements. This is due to several reasons. First, as the new thresholds increased by $160 \mathrm{hm}^{3}$ in both the reserve stored in the Entrepeñas-Buendía system (which rises to $400 \mathrm{hm}^{3}$ ) and in the monthly curve of levels that serves to dictate exceptional hydrological conditions (Royal Decree 2530/1985).

With the new management rules, the reserves in the headwater reservoirs of the Tagus will frequently be below the no-transfer threshold $\left(400 \mathrm{hm}^{3}\right)$ (Figure 3). As a consequence, periods of drought would result in situations where no water would be available for the Segura basin as other resources would be needed to guarantee agricultural and urban supply. This is the currently case with the closure of the TSA between May of 2017 and April 2018. This situation never had been before (temporal closure of the TSA). However, with the rain of the winter and spring, the volume stored reached in the first week of April (2018) a total of $472 \mathrm{hm}^{3}$, so that, according to the present management rules, water could be transferred. The Ministry of Agriculture, based on a report drafted by the technician, decided on April 4th, approved a transfer of $60 \mathrm{hm}^{3}$ from April to June. This measure was applauded from the recipient basin and rejected by the donor. For this last one basin, opposites to the transfer want increase the level of no transfer. For example, is the case of the Government of Castilla-La Mancha that would increase this level until $600 \mathrm{hm}^{3}$ (Diario Información, 2018). All in all, the memorandum is a solution that has allowed guaranteeing more rights at the headwater, but it is not a definitive solution because it does not consider other factors that have affected the 
availability of resources in the recipient basin, the management of demand in both basins, etc. The memorandum is a 'patch' solution that has not solved the problem and the tensions between both basins continue.

Figure 3 Water stored in the reservoirs of Entrepeñas and Buendía (headwater) (1979-2018) $\left(\mathrm{hm}^{3}\right)$ (see online version for colours)

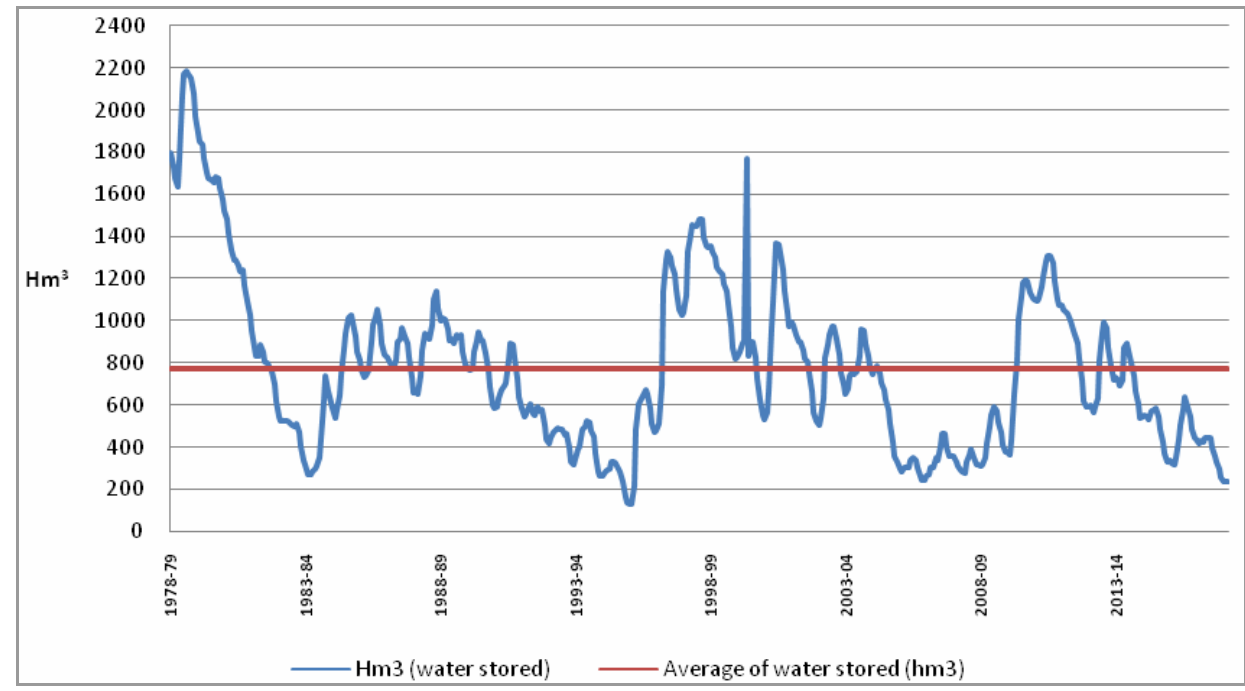

Source: SCRATS (2016), Own elaboration

In the light of these contexts of conflicts over access to water resources, the need to plan current and future water uses has been illustrated by various authors (Gössling et al., 2012). This need is accentuated if the present situation is added to the climate change scenario. In the last three decades a reduction of water resources was recorded in all Spanish river-basin districts. Comparing data on annual supply between 1996-2005 in relation to the mean values of the 1940-1995 period, this reduction amounts to $14.3 \%$ for the country as a whole, with higher values for this reduction (above 20\%) corresponding to the water basins located in the southern half of the Iberian Peninsula and on the Mediterranean coast. For the two river basins that make up the Tagus-Segura system, the reduction was $14.4 \%$ (Tagus, from 10,533 to $9,012 \mathrm{hm}^{3} /$ year) and $38.2 \%$ (Segura, from 817 to $505 \mathrm{hm}^{3} /$ year), the latter district having suffered the largest reduction of all the Spanish river basins (Martín and González, 2015). If the predictions for a reduction and irregularity of precipitations forecast in the climate modelling for the Mediterranean basin (IPCC, 2014) are accurate, the tensions over water use may increase. In this respect, a reduction in precipitation and available water resources of $5 \%$ has been estimated in the Segura basin in the medium term whilst in the Tagus basin this reduction has been estimated at 7\%. Morote et al. (2017b) argue that if these new rules had been functioning since 1979, in theory, the TSA it should had been cancelled on several occasions (19831984, 1992-1993, 1995-1996, 2005-2007, 2008-2009 and 2015-2018) due to drought conditions. They concluded that the function of the TSA is not so much conditioned by the effects of the reduction in precipitation $(-7 \%)$, as by the succession of drought episodes; the new, more conservative and fairer management regulations in favour of the donor basin; and by the increase of the water demand in the headwater of the Tagus. 
Table 3 Postures for and against of the TSA

\begin{tabular}{|c|c|}
\hline Against for the TSA & In favour of the TSA \\
\hline Political & Political \\
\hline $\begin{array}{l}\text { - The TSA is an infrastructure that } \\
\text { has reduced the volumes stored in } \\
\text { the headwater reservoirs } \\
\text { (Entrepeñas and Buendía) }\end{array}$ & $\begin{array}{l}\text { - The TSA is the main infrastructure that has } \\
\text { guaranteed the socio-economic development of } \\
\text { the south-eastern Spain (tourism and } \\
\text { agriculture) }\end{array}$ \\
\hline \multicolumn{2}{|l|}{$\begin{array}{l}\text { - Replacement of the TSA by } \\
\text { desalination }\end{array}$} \\
\hline Social & Social \\
\hline $\begin{array}{l}\text { - Perception in the society that 'there } \\
\text { are no water' }\end{array}$ & $\begin{array}{l}\text { - Thanks to TSA, water is supplied to } 59 \text { villages } \\
\text { of Castilla-La Mancha (donor basin) }\end{array}$ \\
\hline $\begin{array}{l}\text { - Restoration of the heritage, cultural, } \\
\text { emotional, aesthetic and playful } \\
\text { value of the Tagus River }\end{array}$ & $\begin{array}{l}\text { - In the headwater of the Tagus it want to close } \\
\text { the TSA by the assertion that 'there is no water' } \\
\text { but nevertheless it have increased in headwater } \\
\text { the demands of water for urban and agricultural } \\
\text { uses }\end{array}$ \\
\hline $\begin{array}{l}\text { - According to the Ministry of Public } \\
\text { Administration of Castilla-La } \\
\text { Mancha, } 65 \% \text { of Castilian-La } \\
\text { Mancha people are against the TSA }\end{array}$ & $\begin{array}{l}\text { - The TSA water transfers occur whenever there } \\
\text { is surplus guaranteeing the first supply for the } \\
\text { transferor basin }\end{array}$ \\
\hline Environmental & Environmental \\
\hline $\begin{array}{l}\text { - Adopt more sustainable regional } \\
\text { models }\end{array}$ & $\begin{array}{l}\text { - Thanks to the TSA water is supplied to the } \\
\text { National Park of the Tables de Daimiel (donor } \\
\text { basin) }\end{array}$ \\
\hline - Reduction of ecological flows & - The TSA has allowed the reduction of \\
\hline $\begin{array}{l}\text { - Water transfers are rejected and } \\
\text { sustainable agriculture is advocated }\end{array}$ & $\begin{array}{l}\text { overexploitation of aquifers in the southeast of } \\
\text { Spain (recipient basin) }\end{array}$ \\
\hline $\begin{array}{l}\text { - Closure of the TSA for compliance } \\
\text { with the WFD }\end{array}$ & \\
\hline Economical & Economical \\
\hline $\begin{array}{l}\text { - The economy of the villages around } \\
\text { the reservoirs is supported by } \\
\text { tourism (leisure and nautical sports) }\end{array}$ & $\begin{array}{l}\text { - In the headwater, the necessary investments in } \\
\text { supply have not been made with the economic } \\
\text { benefits of the TSA compensation rates }\end{array}$ \\
\hline $\begin{array}{l}\text { - The TSA replacement is defended } \\
\text { by desalinated water in the recipient } \\
\text { basin (but with subsidised water } \\
\text { due to its high cost }-0.60-1 € \mathrm{~m}^{3} \text { ) }\end{array}$ & $\begin{array}{l}\text { - High economic and energy cost of the } \\
\text { production of desalinated water that its makes } \\
\text { unviable the replacement by the TSA }\end{array}$ \\
\hline \multirow[t]{2}{*}{$\begin{array}{l}\text { - The water price of the TSA is cheap } \\
\left(0.09 € / \mathrm{m}^{3}\right)\end{array}$} & $\begin{array}{l}\text { - } 42 \% \text { marketed in vegetable and fruit exports in } \\
\text { Spain is marketed in the area benefiting from } \\
\text { the TSA ( } 4,999 \text { billion euros). }\end{array}$ \\
\hline & $\begin{array}{l}\text { - TSA guarantee supply to more than } 2.5 \text { million } \\
\text { inhabitants in the recipient basin (provinces of } \\
\text { Almeria, Alicante and Murcia, that could } \\
\text { increase in } 1 \text { million more due to the touristic } \\
\text { uses in summer. }\end{array}$ \\
\hline
\end{tabular}

Source: Own elaboration 
The headwaters of the Tagus share with the Segura similarity in the precipitation regime and in the atmospheric causes of the episodes of drought, and this determines that in periods of drought the tensions increase. These situations are explained by a climatic factor (drought), but also by the increase in demand owing to the failure to implement correct water management based on climate. Thus, in the Tagus Basin Plan (2015-2021), the demands on the headwaters have intensified to supply the urban developments of Madrid and the banks of the river Tagus $\left(184 \mathrm{hm}^{3} /\right.$ year) (the most exposed and vulnerable to drought situations), which has $45 \%$ of the water available in the whole district to satisfy $85 \%$ of consumption. For the Segura basin, where a deficit is recognised of $400 \mathrm{hm}^{3} /$ year,there are demands for self-sufficiency of resources that would be made possible by the A.G.U.A. Programme (2004) which has favoured large scale desalination (March et al., 2014; Swyngedouw and Williams, 2016), although a fierce debate has also been generated on the Spanish Mediterranean coast regarding the viability of the functioning of the desalination plants (Morote et al., 2017a) as has occurred in other regions such as California (Stokes and Horvath, 2006).

In the recipient basin, the total production capacity of the seven main desalination plants amounts to $350 \mathrm{hm}^{3} /$ year, although this volume has never been produced due to the high price of water as a result of high energy consumption. This high price determines that agricultural uses cannot afford it (Morote et al., 2017a). For example, according to the irrigators of the SCRATS, they cannot pay more than $0.30 € / \mathrm{m}^{3}$ for citrus $(61,316 \mathrm{ha}$; the $41 \%$ of the irrigation surface in the recipient basin). Also, it is important to mention the problem of the Boron. Desalination produce water with $0.5 \mathrm{mg} / \mathrm{l}$ of Boron, however, citrus can not hold more than this limit. However, in words of Swyngedouw and Williams (2016), desalination looks set to become the great solution, although at the moment it is economically more expensive and unfeasible for agricultural use unless a political price is applied. Furthermore, according to the detractors of the TSA in the donor basin, the desalination plants built on the Mediterranean coast should produce subsidised water (at a price equal to that of the TSA, at $0.09 € / \mathrm{m}^{3}$ ). At present this is an unfeasible solution, even though desalination is a strategic resource for circumstantial alleviation of the decrease of other resources (as has occurred with the river Taibilla, a tributary of the Segura) or with the TSA. It cannot be considered as a substitute resource in the long-term, owing to the price $\left(0.09 € / \mathrm{m}^{3}\right.$ compared to $\left.0.60 € / \mathrm{m}^{3}\right)$ and to energy consumption $\left(1.11 \mathrm{kWh} / \mathrm{m}^{3}\right.$ compared to $4.50 \mathrm{kWh} / \mathrm{m}^{3}$ ) (Morote et al., 2017a).

All the same, according to Morote et al. (2017b), there would be the option of carrying out a scheduled closure of the current TSA infrastructure. This measure, also controversial, would require the agreement of the two basins (donor and recipient) and entail a series of water compensation measures for the users of the Segura basin. The transferred flows would be replaced by others of diverse origins (desalination) and compensation between 3,021 and 9,161 million euros would be paid if water is not guaranteed (Melgarejo et al., 2009). If the same socio-economic model in the recipient basin continues, there are the options of measures under the Common Agricultural Policy (CAP) ('greening') to improve the efficiency of agricultural use (in both basins), and a complete replacement of the TSA by desalination (increasing the current capacity of 350 $\mathrm{hm}^{3} /$ year to $540 \mathrm{hm}^{3} /$ year). This scenario (definitive closure of the TSA) would be complex to implement, and would require a massive effort by the authorities to educate the current users of the transferred water in order to change attitudes, behaviours and the socio-economic model developed over decades. However, fortunately, the donor basin 
will increase the environmental quality and quantity of the Tagus River due to the cancellation of the transfers to the south-east of Spain.

The TSA is an example from which to learn and compare with other international cases regarding the controversy between basins. In the Los Angeles Region, the City of Los Angeles (with a population reaching 4 million people) imports nearly $90 \%$ of its water from sources outside the city. However, climate change, population growth, competing demands, water-quality concerns, and environmental restoration projects have all had a large impact on the dependency of this city on future water importation. Of the five main water sources that supply this area (Los Angeles Aqueduct, Colorado River, California Aqueduct, local groundwater and reclaimed water) most will be impacted by climate change, water quality, energy and cost constraints (Ashoori et al., 2015). Equal consequences and the implications of climate change were argued by Schwarz (2015) in California in relation to water dependence under IBWT. Similar implications can be shown to exist in the study case (South-East of Spain). It is a semi-arid region with an important dependence of water transfers $(60 \%$ of the water resources available from the TSA), an area with competing demands (tourist vs. irrigation uses) and controversy around desalination due its high costs. Restoration of the TSA will generate different ecological impacts in the recipient basin as the over-exploitation of aquifers increases and $\mathrm{CO}_{2}$ emissions rise due to the increase in the production capacity of desalination in the Mediterranean in order to replace water transfers for the TSA.

\section{Conclusions}

In Spain, the functioning of the TSA has generated diverse and continuous controversies between the donor (Tagus) and recipient (Segura) basins. On the one side, those who oppose this transfer from the centre of the Iberian Peninsula accuse those in the south-east of appropriating 'their resources' without recipient anything in exchange and prejudicing the environment with the reduction of ecological flows and socio-economic development. On the other, the recipients mention the far-reaching socio-economic impact of the uses benefited by this water. Before the temporal closure of the TSA in May of 2017 due to the current drought, $60 \%$ of the productive wealth of the recipient basin of the TSA depended on the contribution of the waters from the river Tagus, owing to which these recipient areas should seek solidarity with the donors and never forget their dependence on them. During the last closure of the TSA, water supplies were replaced by the increase of the desalination production and the start of the work of desalination plants that were closed. However, as argued by Morote et al. (2017a), desalination and water-transfer schemes are not panaceas in themselves; rather, they should be considered in terms of technological parameters tailored to the circumstances of each geographical and socio-economic environment.

The TSA users are in a situation of vulnerability, but it is the consequence of having articulated an economic system around a water that there is not. The transfers spread the scarcity and generate political conflicts. To solve these issues hydrological policy must be more transparent, obey the law, change the mentality of confederations and involve the universities. Likewise, the adoption of demand management policies must become more relevant. Policies aimed at increasing the resources available to meet demands 
generate a vicious cycle that does not solve existing problems, but rather prolongs and accentuates them over time.

The new rules on the exploitation of the TSA provide a very relevant example of water governance. It is a political pact that sets out to boost the water planning of the Tagus and of the river-basin districts of the Segura, providing legal security and institutional stability to the irrigation and supplies that currently depend on the infrastructure, while respecting in all cases the prevalence of the demands in the donor basin that logically take priority (Melgarejo et al., 2014). The memorandum is a solution that has not satisfied anyone (in favour or against). The memorandum is a 'patch' solution that has not solved the problem because the tensions between both basins continue.

Added to the uncertainty regarding future water resources in the framework of global warming due to the anthropogenic greenhouse effect which, in some regions of the world, such as Spain, may cause a reduction in precipitation and, therefore, a reduction in the water circulating in the rivers (Lobanova et al., 2016; Valdés-Abellán et al., 2017). All of this means that the future functioning of the TSA is uncertain since, on one hand, a reduction in water resources has been forecast together with an increase in demands in the headwater $\left(184 \mathrm{hm}^{3} /\right.$ year); thirdly, owing to the effects of the new management rules that increased the no-transfer level from $240 \mathrm{hm}^{3}$ to $400 \mathrm{hm}^{3}$; fourthly, there are desalination plants without demand in the recipient basin. The impact of these factors will be to condition the normal functioning of the TSA, and therefore, other resources have been assessed (such as desalination) as solutions to replace water transfers. Undoubtedly, it would be necessary to achieve greater efficiency in water use, both in the Tagus and Segura basins, and to increase the supply of non-conventional resources (desalination and treated reused water) at a price and quality acceptable to the various stakeholders. Furthermore, it is important to consider the necessity of improving the quality of the treated water, increase efficient management of the water demand and supply, subsidise the desalinated water in the recipient basin, and establish a national water-tariff system that allows the incorporation of the resources provided by the desalination of sea water (Morote et al., 2017b).

In conclusion, from the analysis of the political, social, environmental and economic controversy generated around the TSA it is appropriate to point out that, since its construction in 1979 this infrastructure has been accompanied by conflicts and interests often based on falsities or half-truths, both by the defenders and detractors of this infrastructure. The solution lies in a greater integration of all the available water resources of diverse origin (water from currently transfers, desalination, groundwater, surface water, treated reused, etc.), always with appropriate studies of water management resources, achieving 'water solidarity' between all the players involved and not 'politicising' a resource of vital importance in a country where the largest socio-economic developments are located where water is most scarce. However, politicisation can unearth fundamental tensions which may be in or outside the water domain, and provoke a debate on what is the common good and how scarce values should be allocated (Heywood, 2002). 


\section{Acknowledgements}

The results presented in this research are part of the research project 'Uses and management of non-conventional water resources on the coast of Valencia and Murcia as an adaptation strategy to drought' funded by the Spanish MINECO under grant number CSO2015-65182-C2-2-P.

\section{References}

Ashoori, N., Dzombak, D.A. and Small, M.J. (2015) 'Sustainability review of water-supply options in the Los Angeles Region', Water Resour. Plan. Manag., Vol. 141, No. 12, p.A4015005, https://doi.org/10.1061/(ASCE)WR.1943-5452.0000541.

Baeza, D. (2013) 'Estado ecológico de los ríos que forman la red hidrográfica del territorio español de la Demarcación del Tajo', El Tajo. Historia de un río ignorado, Fundación Nueva Cultura del Agua, pp.89-128.

CMM (2018) Regantes del Levante reivindican en Madrid más agua, 07 March [online] http://www.cmmedia.es/noticias/castilla-la-mancha/regantes-del-levante-reivindican-enmadrid-mas-agua/ (accessed 03 April 2018).

Del Moral, L. and Silva Pérez, R. (2006) 'Grandes zonas regables y reparto del agua en España. El caso de la cuenca del Guadalquivir', Mélanges de la Casa de Velázquez, Monographicissue: Partage de l'eau en Espagne, au Portugal et auMaroc, Vol. 36, No. 2, pp.125-148.

Del Moral, L., Martínez-Fernández, J. and Hernández-Mora, N. (2017) 'Ongoing dialogues with Erik Swyngedouw about desalination in Spain', Water International, Vol. 42, No. 3, pp.333-338.

Diario Información (2018) El Consell solo aceptaráunalínearoja de $400 \mathrm{hm} 3 e n$ el trasvase Tajo-Segura in Benito, F.J., 25 September [online] https:/www.diarioinformacion.com/ alicante/2018/09/26/consell-aceptara-linea-roja-400/2066988.html (accessed 08 October 2018).

Estevan, A., La Calle, A. and Naredo, J.M. (2007) Las series hidrológicas en la instrucción de Planificación Hidrológica [online] http://www.unizar.es/fnca/docu/docu172.pdf (accessed 15 April 2018).

European Parliament (2016) Proyecto de Informe de Misión y de Recomendaciones, a raíz de la visita de inspección realizada en España, del 8 al 10 de febrero de 2016, Comisión de Peticiones.

Federación Española de Asociaciones de Productores Exportadores de Frutas y Hortalizas (FEPEX) (2016) Datos del Sector [online] http://www.fepex.es/datos-del-sector/exportacionimportacion-espa\%C3\%B1ola-frutas-hortalizas (accessed 01 April 2017).

Ferreira, M.T. (2013) 'Calidad ecológica en la Demarcación Hidrográfica del Tajo: Una perspectiva integrada', El Tajo. Historia de un río ignorado, Fundación Nueva Cultura del Agua, pp.145-171.

Fundación Nueva Cultura del Agua (FNCA) (2016) 'A vueltas con el trasvase Tajo-Segura', Núria Hernández-Mora [online] http://www.fnca.eu/73-boletin/titulos/567-a-vueltas-con-el-trasvasetajo-segura (accessed 10 April 2017).

Gallego Bernad, M.S. (2013) 'El abastecimiento de Madrid y el trasvase Tajo-Segura en la planificación y gestión de la Demarcación Hidrográfica del Tajo', El Tajo. Historia de un río ignorado, Fundación Nueva Cultura del Agua, pp.35-88.

Ghassemi, F. and White, I. (2007) Inter-Basin Water Transfer: Case studies from Australia, United States, Canada, China and India, Cambridge University Press, New York.

Gil, A. and Morales, A. (1995) Planificación Hidráulica en España, Fundación Caja del Mediterráneo, Murcia. 
Gil, E., Bernabé, M.B. and Gómez, J.M. (2017) 'Las políticas de trasvases de agua y desalación en España, sus repercusiones en la ordenación del territorio del Sureste', XXV Congreso de la AGE. 50 Años de congresos de Geografia, Madrid, pp.2480-2489.

Gil, E., Martínez, R. and Gómez, J.Mª (2018) 'El trasvase Tajo Segura en España (1978-2018). Continuidad y futuro', Revista Tecnolgia y Ciencias del Agua Tyca, México.

Gómez, J.Mª (Coord.) (2017) El trasvase Tajo-Segura. Propuestas para su continuidad y futuro, Editorial Académica Española, Saarbrüchen (Alemania).

González-Escolano, E. (2009) 'Análisis económico de las tarifas de conducción de aguas en el Acueducto Tajo-Segura', in Melgarejo Moreno, J. (Dirc.): El Trasvase Tajo-Segura: repercusiones económicas, sociales y ambientales en la cuenca del Segura, pp.197-269, Caja de Ahorros del Mediterráneo, University of Alicante, Alicante, Spain.

Gorostiza, S., March, H. and Saurí, D. (2017) 'Flows from beyond the Pyrenees. The Rhône River and Catalonia's search for water independence', Political Geography, Vol. 60, pp.132-142.

Gössling, S., Peeters, P., Hall, C.M., Ceron, J.P., Dubois, G., Lehmann, L. and Scott, D. (2012) 'Tourism and water use: supply, demand and security, an international review', Tourism Management, Vol. 33, No. 1, pp.1-15.

Hernández Hernández, M. and Morales Gil, A. (2009) 'La hortofruticultura y las aguas del Trasvase Tajo-Segura: repercusiones socio-económicas', in Melgarejo Moreno, J. (Dirc.): El Trasvase Tajo-Segura: repercusiones económicas, sociales y ambientales en la cuenca del Segura, pp.413-462, Caja de Ahorros del Mediterráneo, University of Alicante, Alicante Spain.

Hernández Hernández, M., Rico Amorós, A.M. and Juárez Sánchez, C. (2010) 'Conflicts over water and land use on the coastline of the region of Valencia: agriculture versus the urban-tourist city', WIT Transactions on Ecology and the Environment, Vol. 129, pp.405-416.

Hernández-Mora, N. (2013) 'Presentación', in Baeza Sans, D. et al. (Eds.): El Tajo. Historia de un río ignorado, Fundación Nueva Cultura del Agua, pp.13-22.

Hernández-Mora, N., Del Moral Ituarte, L., La-Roca, F., La Calle, A. and Schmidt, G. (2014) 'Interbasin water transfer in Spain: interregional conflicts and governance responses', Schneider-Madanes, G. (Ed.): Globalized Water: A Question of Governance, Vol. 1, pp.175-194.

Heywood, A. (2002) Politics, Palgrave Foundations, Palgrave.

Hommes, L. and Boelens, R. (2017) 'Urbanizing rural waters: rural-urban water transfers and the reconfiguration of hydrosocial territories in Lima', Political Geogr., Vol. 2, No. 57, pp.71-80.

Intergovernmental Panel on Climate Change (IPCC) (2014) 'Climate change 2014: synthesis report', in Pachauri, R.K. and Meyer, L.A. (Eds.): Contribution of Working Groups I, II and III to the Fifth Assessment Report of the Intergovernmental Panel on Climate Change, Geneva, Switzerland [online] http://www.ipcc.ch/report/ar5/syr/ (accessed 4 May 2018).

Kefayati, M., Saghafian, B., Ahmadi, A. and Babazadeh, H. (2018) 'Empirical evaluation of river basin sustainability affected by inter-basin water transfers using composite indicators', Water and Environmental Journal, Vol. 32, No. 1, pp.104-111.

La Roca, F. and Martínez, J. (2018) 'Retos de la planificación y gestión del agua en España', Informe del observatorio de políticas del agua 2017, Fundación Nueva Cultura del Agua.

Li, Y. and Han, M. (2018) 'Embodied water demands, transfers and imbalance of China's mega-cities', Journal of Cleaner Production, Vol. 172, pp.1336-1345, https://doi.org/10.1016/ j.jclepro.2017.10.191.

Lobanova, A., Koch, H., Liersch, S., Hatterman, F.F. and Krysanova, V. (2016) 'Impacts of changing climate on the hydrology and hydropower production of the Tajus River basin', Hydrological Processes, Vol. 30, No. 26, pp.5039-5052, DOI: 10.1002/hyp.10966.

López, J.C. (2018) 'Interbasin water transfers and the size of regions: an economic geography example', Water Resources and Economics, No. 21, pp.40-55, https://doi.org/10.1016/ j.wre.2017.10.005. 
López-Gunn, E., Willaarts, B., Rica, M., Corominas, J. and Llamas, R. (2013) 'The Spanish water? Pressure cooker?: Threading the interplay between resource resilient water governance outcomes by strengthening the robustness of water governance processes', International Journal of Water Governance, Vol. 1, No. 1-2, pp.13-40.

March, H., Hernández, M. and Saurí, D. (2015) 'Percepción de recursos convencionales y no convencionales en áreas sujetas a estrés hídrico: el caso de Alicante', Revista de Geografía Norte Grande, No. 60, pp.153-172.

March, H., Saurí, D. and Rico, A.M. (2014) 'The end of scarcity? Water desalination as the new cornucopia for Mediterranean Spain', Journal of Hydrology, Vol. 519, pp.2642-2652, https://doi.org/10.1016/j.jhydrol.2014.04.023.

Martín Barajas, S. and González Briz, E. (2015) Los Efectos del Cambio Climático Sobre el Agua en España y la Planificación Hidrológica, Ecologistas en Acción, Madrid, Spain [online] https://www.ecologistasenaccion.org/IMG/pdf/informe-agua-cc-castellano.pdf (accessed 10 February 2018).

Martínez Menchón, M. and Senent Alonso, M. (2007) 'El agua en el Campo de Cartagena', Revista Murciana de Antropología, No. 14, pp.47-61.

Mehta, L. (2011) 'The social construction of scarcity: the case of water in Western India', in Peet R., Robbins, P. and Watts, M.J. (Eds): Global Political Ecology, pp.371-386, Routledge, London.

Melgarejo Moreno, J. (2000) 'Balance económico del trasvase Tajo-Segura', Investigaciones Geográficas, No. 24, pp.69-95.

Melgarejo Moreno, J., Molina Giménez, A. and López Ortiz, M.I. (2014) 'El Memorándum sobre el trasvase Tajo-Segura. Modelo de resolución de conflictos hídricos', Revista Aranzadi de Derecho Ambiental, No. 24, pp.1-16.

Melgarejo Moreno, P. and Martínez Nicolas, J.J. (2009) 'Influencia económica del Trasvase Tajo-Segura en la agricultura de las provincias de Murcia, Alicante y Almería', in Melgarejo Moreno, J. (Dirc.): El Trasvase Tajo-Segura: repercusiones económicas, sociales y ambientales en la cuenca del Segura, pp.343-411, Caja de Ahorros del Mediterráneo, University of Alicante, Alicante..

Melgarejo, J., Molina, A. and Del Villar, A. (2009) La Responsabilidad Patrimonial del Estado ante la Hipotética Reducción o Cancelación del Trasvase Tajo-Segura, Confederación Empresarial de la provincia de Alicante (COEPA), Alicante, Spain.

Mellado Ruiz, L. (2010) Aguas y ordenación del territorio en el contexto de lareforma estatutaria, Comares, Granada.

Molina, A. and Melgarejo, J. (2016) 'Water policy in Spain: seeking a balance between transfers, desalination and wastewater reuse', International Journal of Water Resources Development, Vol. 32, No. 5, pp.781-798.

Morales Gil, A., Rico Amorós, A.M. and Hernández, M. (2005) 'El trasvase Tajo-Segura', Observatorio Medioambiental, No. 8, pp.73-110.

Morote, A.F. and Hernández, M. (2017) 'El uso de aguaspluvialesen la ciudad de Alicante. De Viejas ideas a nuevosenfoques', Papeles de Geografía, Vol. 63, pp.7-25 [online] $\mathrm{http} / / / \mathrm{dx}$.doi.org/10.6018/geografia/2017/267531.

Morote, A.F., Hernández, M. and Rico, A.M. (2016) 'Causes of domestic water consumption trends in the City of Alicante: exploring the links between the housing bubble, the types of housing and the socio-economic factors', Water, Vol. 8, No. 374, pp.1-18, DOI: 10.3390/w8090374.

Morote, A.F., Rico, A.M. and Moltó, E. (2017a) 'Critical review of desalination in Spain: a resource for the future?', Geographical Research, pp.1-12, DOI: 10.1111/1745-5871.12232.

Morote, A.F., Olcina, J. and Rico, A.M. (2017b) 'Challenges and proposals for socio-ecological sustainability of the Tagus-Segura Aqueduct (Spain) under climate change', Sustainability, Vol. 9, No. 11, pp.1-24, DOI: 10.3390/su9112058.

Plataforma de Toledo en Defensa del Tajo (2016) [online] http://tajotoledo.es/?page_id=53 (accessed 01 May 2017). 
Poddar, R., Qureshi, M.E. and Shi, T. (2014) 'A comparison of water policies for sustainable irrigation management: the case of India and Australia', Water Resources Management, Vol. 28, No. 4, pp.1079-1094.

Rico Amorós, A.M., Arahuetes Hidalgo, A. and Morote Seguido, A.F. (2016) 'Depuración y reutilización de aguas residuales en las regiones de Murcia y Valencia', in Vera, J.F., Olcina Cantos, J. and Hernández, M. (Eds.): Paisaje, cultura territorial y vivencia de la Geografia, Libro Homenaje al profesor Alfredo Morales Gil, pp.1.169-1.202, Serviciode Publicaciones de la Universidad de Alicante, Alicante.

Rogers, S., Barnett, J., Webber, M., Finlayson, B. and Wang, M. (2016) 'Governmentality and the conduct of water: China's South-North water transfer project', Transactions of the Institute of British Geographers, Vol. 41, No. 4, pp.429-441.

Sala Díez, I. (2009) 'El debate sobre el Trasvase Tajo-Segura en los medios de comunicación', in Melgarejo Moreno, J. (Dirc.): El Trasvase Tajo-Segura: repercusiones económicas, sociales y ambientales en la cuenca del Segura, pp.587-635, Caja de Ahorros del Mediterráneo, University of Alicante, Alicante.

San Martin González, E. (2011) Un análisis económico de los trasvases de agua intercuencas: el trasvase Tajo-Segura, Aquae Tesis, Universidad Nacional de Educación a Distancia.

Sánchez Pérez, M.A. (2018) Informe hidrológico sobre la gestión del macro embalse de Entrepeñas y Buendía, Universidad de Castilla-La Mancha.

Saurí, D. and Del Moral, L. (2001) 'Recent development in Spanish water policy. Alternatives and conflicts at the end of the hydraulic age', Geoforum, Vol. 32, No. 3, pp.351-362.

Schwarz, A.M. (2015) 'California central valley water rights in a changing climate', San Francisco Estuary and Watershed Science, Vol. 13, p.2 [online] http://dx.doi.org/10.15447/ sfews.2015v13iss2art2.

SCRATS (2016) Especial ABC. 37 Años Trasvase Tajo-Segura, Sindicato Central de Regantes del Acueducto Tajo-Segura.

Sindicato Central de Regantes del Acueducto Tajo-Segura (SCRATS) (2017) Análisis de soluciones para el aporte de recursos complementarios a las zonas abastecidas por el ATS, Actuaciones viables a corto, medio y largo plazo.

Snaddon, C.D., Davies, B.R. and Wishart, M.J. (1999) A Global Overview of InterBasin Water Transfer Schemes, with an Appraisal of their Ecological, Socio-Economic and Socio-Political Implications, and Recommendations for Their Management, Water Research Commission Report $\mathrm{n}^{\circ}$ TT120/00, Water Research Commission, Pretoria.

Stokes, J. and Horvath, A. (2006) 'Life-cycle energy assessment of alternative supply systems', International Journal of LCA, Vol. 11, p.335, DOI: 10.1065/lca2005.06.214.

Sun, J., Dang, Z. and Zheng, S. (2017) 'Development of payment standards for ecosystem services in the largest interbasin water transfer projects in the world', Agricultural Water Management, Vol. 182, pp.158-164, https://doi.org/10.1016/j.agwat.2016.06.025.

Swyngedouw, E. (2015) Liquid Power: Contested hydro-Modernities in Twentieth Century Spain, MIT Press, Cambridge, United States.

Swyngedouw, E. and Williams, J. (2016) 'From Spain's hydro-deadlock to the desalination fix', Water International, Vol. 41, No. 1, pp.54-73.

Tan, F. and Bi, J. (2018) 'An inquiry water transfer network of the Yangtze River Economic Belt in China', Journal of Cleaner Production, Vol. 176, pp.288-297, https://doi.org/10.1016/ j.jclepro.2017.12.129.

Thapa, B.R., Ishidaira, H., Pandey, V.P., Bhandari, T.M. and Shakya, N.M. (2018) 'Evaluation of water security in Katmandu Valley before and after water transfer from another basin', Water, Vol. 10, No. 2, p.224.

Valdés-Abellán, J., Pardo, M.A. and Tenza-Abril, A.J. (2017) 'Observed precipitation trend changes in the western Mediterranean region', Int. J. Climatol. [online] https://doi.org/ 10.1002/joc. 4984 . 
Venkatachalam, L. and Balloni, K. (2018) 'Water transfer from irrigation tanks for urban use: can payment for ecosystem services produce efficient outcomes?', International Journal of Water Resources Development, Vol. 34, No. 1, pp.51-65.

Vera, J.F., Olcina, J. and Díez, D. (2009) 'Repercusiones del Trasvase Tajo-Segura en el sector turístico de la Región de Murcia', in Melgarejo Moreno, J. (Dirc.): El Trasvase Tajo-Segura: repercusiones económicas, sociales y ambientales en la cuenca del Segura, pp.465-516, Caja de Ahorros del Mediterráneo, University of Alicante, Alicante..

Vicente García, M. and Richard, V. (2009) 'Afección ambiental de la potencial cancelación del Trasvase Tajo-Segura en la cuenca receptora', in Melgarejo Moreno, J. (Dirc.): El Trasvase Tajo-Segura: repercusiones económicas, sociales y ambientales en la cuenca del Segura, pp.519-539, Caja de Ahorros del Mediterráneo, University of Alicante, Alicante..

Zhuang, W. (2016) 'Eco-environmental impact of inter-basin water transfer projects: a review', Environmental Science and Pollution Research, Vol. 23, No. 13, pp.12867-12879. 